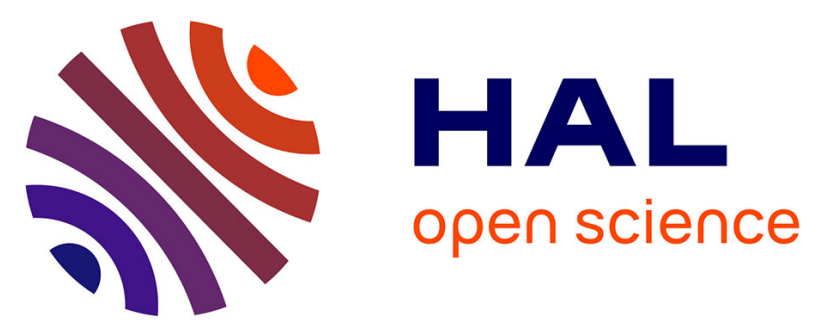

\title{
Cyclic AMP enhances gene expression, synthesis and release of newly synthesized alpha and luteinizing hormone beta subunits in cultured rat anterior pituitary cells
}

Anna Starzec, Mohieddine Moumni, Gisela d'Angelo, Yannick Lerrant, Marian Jutisz, Raymond Counis

\section{To cite this version:}

Anna Starzec, Mohieddine Moumni, Gisela d'Angelo, Yannick Lerrant, Marian Jutisz, et al.. Cyclic AMP enhances gene expression, synthesis and release of newly synthesized alpha and luteinizing hormone beta subunits in cultured rat anterior pituitary cells. Neurochemistry International, 1989, 15 (3), pp.259-264. 10.1016/0197-0186(89)90131-9 . hal-03034089

\author{
HAL Id: hal-03034089 \\ https://hal.science/hal-03034089
}

Submitted on 9 Dec 2021

HAL is a multi-disciplinary open access archive for the deposit and dissemination of scientific research documents, whether they are published or not. The documents may come from teaching and research institutions in France or abroad, or from public or private research centers.
L'archive ouverte pluridisciplinaire HAL, est destinée au dépôt et à la diffusion de documents scientifiques de niveau recherche, publiés ou non, émanant des établissements d'enseignement et de recherche français ou étrangers, des laboratoires publics ou privés. 


\title{
CYCLIC AMP ENHANCES GENE EXPRESSION, SYNTHESIS AND RELEASE OF NEWLY SYNTHESIZED ALPHA AND LUTEINIZING HORMONE BETA SUBUNITS IN CULTURED RAT ANTERIOR PITUITARY CELLS*
}

\author{
Anna Starzec, Mohieddine Moumni, Gisèle D’Angelo-Bernard, Yannick Lerrant, \\ Marian Jutisz and Raymond Counis \\ Laboratoire des Hormones Polypeptidiques, Centre National de la Recherche Scientifique, \\ 91198 Gif-sur-Yvette, France
}

(Received 8 February 1988; accepted 9 March 1989)

\begin{abstract}
We have previously demonstrated that GnRH stimulates the synthesis of both the $\alpha$ and LH $\beta$ polypeptide chains, an effect which was reproduced in a non additive manner by direct activation of protein kinases $\mathrm{A}$ and $\mathrm{C}$, and abolished by actinomycin $\mathrm{D}$. In the present study, we examined the effects in monolayer cultures from rat anterior pituitary cells of 8-Br-cAMP and cholera toxin, on $\alpha$ and LH $\beta$ subunit mRNA levels and in parallel the synthesis and release of the subunits. RNA blot hybridization analysis with cDNA probes demonstrated that $\alpha$ and LH $\beta$ mRNA levels increased by 8.9- and 4.7-fold, respectively, after a $5 \mathrm{~h}$-incubation in the presence of $6 \mathrm{nM}$ cholera toxin and 7.1 - and 2.9 -fold in the presence of $1.5 \mathrm{mM} 8$-Br-cAMP. Under the same conditions, $\left[{ }^{35}\right.$ S $]$ methionine incorporation into $\alpha$ and LH $\beta$ subunits was optimally stimulated, by 2.8 -fold and 1.7 to 2.2 -fold, respectively, whether the cAMP analogue 8-Br-cAMP or cholera toxin, an endogenous cAMP generator, were employed. Further, in addition to synthesis, 8-Br-cAMP appeared to increase release of neosynthesized $\alpha$ and $\mathrm{LH} \beta$ polypeptides, and in this respect, 8-Br-cAMP was more effective than GnRH. In contrast, 8-Br-cAMP had a weak, non significant effect compared to GnRH on the release of total radioimmunoassayable $\mathrm{LH}$ in the cell media. These data provide the first direct evidence for a stimulation of $\alpha$ and $\mathrm{LH} \beta$ gene expression by cyclic AMP, which accounts for an increase in subunit synthesis. They suggest that cAMP, as previously shown for diacylglycerols, is a potent candidate for an intracellular mediator of the GnRH effects on subunit synthesis and that it is largely responsible for sustained (protein synthesis-dependent) LH release.
\end{abstract}

Neurohormonal control of reproduction occurs in the higher vertebrates via the modulation of secretion by the hypothalamus of a decapeptide, gonadotropin-

*This refereed paper was presented at a symposium on "Régulations Hypothalamo-Hypophyso-Gonadiques" as part of the 18th Colloque de la Société de Neuroendocrinologie Expérimentale, joint meeting with the British Neuroendocrine Group, at Rennes, France, 7-9 September 1988. The meeting was organised by Professor J. Duval (Laboratory of Molecular Endocrinology, CNRS URA 256, Campus de Beaulieu, 35042 Rennes, France) and by Professor J. Morris (Department of Human Anatomy, South Parks Road, Oxford OXI 3QX, U.K.). Professor Duval also acted as Executive Editor in the refereeing of this article.

Address all correspondence to: Dr R. Counis, Laboratoire des Hormones Polypeptidiques, CNRS, 91198 Gif-surYvette Cédex, France.

Abbreviations: GnRH, gonadotropin-releasing hormone; LH, luteinizing hormone; cAMP, adenosine $3^{\prime}: 5^{\prime}$-cyclic monophosphate; Br-cAMP, 8-bromoadenosine 3':5'cyclic monophosphate. releasing hormone (GnRH) (Kalra and Kalra, 1983). $\mathrm{GnRH}$ regulates in the gonadotropic cells of the anterior pituitary gland both the synthesis and the release of the gonadotropins luteinizing hormone (LH) and follicle stimulating hormone (FSH). Each of these hormones is a heterodimeric glycoprotein that is comprised of two non covalently linked subunits, a common $\alpha$ and a unique $\beta$ subunit. It has become evident during the past few years that GnRH stimulates the synthesis of LH polypeptide chains and the accumulation of LH mRNAs (Starzec et al., 1986, 1988a; Papavasiliou et al., 1986; Leung et al., 1987; Ramey et al., 1987; Andrews et al., 1988; Hamernik and Nett, 1988; Hubert et al., 1988; Lalloz et al., 1988a). However, the mechanisms by which the GnRH effects on synthesis are mediated within the gonadotropic cells are still unclear. Using anterior pituitary cells in culture, we have recently demonstrated that direct activation of protein kinases $\mathrm{A}$ and $\mathrm{C}$ stimulated, like GnRH, and in a non additive 
manner, the synthesis of $\alpha$ and $\mathrm{LH} \beta$ polypeptide chains, suggesting cAMP and diacylglycerols interplay in the mediation of GnRH effects inside the cell (Starzec et al., 1989). Furthermore, and consistent with this hypothesis, it has been shown that the diacylglycerol analogue 12-O-tetradecanoyl phorbol 13-acetate was as potent as $\mathrm{GnRH}$ at increasing the cell content of LH mRNAs (Andrews et al., 1988; Starzec et al., in preparation). In the present study, we have investigated the effects of cyclic AMP (cAMP) on $\alpha$ and LH $\beta$ mRNA in parallel to subunit synthesis and release, using cultured rat anterior pituitary cells incubated in the presence of either the cell permeant cAMP analogue 8-Br-cAMP $(\mathrm{Br}-$ cAMP), or cholera toxin which generates production of cAMP in adenylate cyclase containing cells.

\section{EXPERIMENTAL PROCEDURES}

\section{Materials}

The materials for cell dispersion and culture were supplied either by Eurobio, Paris, France (MEM-Eagle, HAM F-10 media and foetal calf serum) or by Nunclon, Roskilde, Denmark (tissue culture dishes). $\left[{ }^{35} \mathrm{~S}\right]$ Methionine $(1100 \mathrm{Cj} /$ mmol) was purchased from the Commissariat à l'Energie Atomique (Saclay, France). $\left[\alpha-{ }^{32} \mathrm{P}\right] \mathrm{dCTP}(400 \mathrm{Ci} / \mathrm{mmol})$, DNA modifying enzymes, nylon filters and random priming DNA labelling kit were from Amersham (Little Chalfont, U.K.). Deoxynucleotides and 8-Br-cAMP were supplied by Boehringer (Manheim, F.R.G.) and cholera toxin by Sigma (St Louis, Mo., U.S.A.). Lipidex was from Packard (Downers Grove, Ill., U.S.A.). All other reagents were A-grade.

The rabbit antisera against reduced and carboxymethylated bovine $\alpha$ and $\mathrm{LH} \beta$ subunits were generously donated by Dr J. G. Pierce. The rat LH RIA kit was obtained from the National Hormone and Pituitary Program (Baltimore, Md, U.S.A.).

\section{Pituitary cell cultures}

Anterior pituitary glands were excised from adult (9-10 week-old, $300-350 \mathrm{~g}$ ) male Wistar rats (laboratory breeding) which had been castrated 15 days earlier, and the tissue was enzymatically dispersed using the trypsin dissociation procedure as described previously (Starzec et al., 1986). The cells $\left(3 \times 10^{6}\right)$ were plated in tissue culture dishes $(35 \mathrm{~mm}$ dia $)$ in $150 \mu 1$ of HAM F-10 medium supplemented with $10 \%$ foetal calf serum depleted in steroids by chromatography on Lipidex. After 1.5-2 h (the time necessary for cell attachment to the surface of the dish) the culture medium volume was brought to $2 \mathrm{ml}$. The cells were cultured for 3 days at $37^{\circ} \mathrm{C}$ in a water and $20 \% \mathrm{O}_{2} / 75 \% \quad \mathrm{~N}_{2} / 5 \% \mathrm{CO}_{2}$ saturated atmosphere before being used in experiments.

\section{In situ biosynthesis}

Incubation, radioactive subunit isolation and scintillation counting were essentially as previously described (Starzec et al., 1986, 1988a). Briefly, proteins were labelled by incubating cells in the presence of $\left[{ }^{35} \mathrm{~S}\right] \mathrm{Met}(75 \mu \mathrm{Ci} / \mathrm{dish})$ in $500 \mu \mathrm{l}$ Krebs-Ringer medium buffered by $25 \mathrm{mM} N^{\prime}$ 2-hydroxy ethyl piperazine- $N$-2-ethane-sulphonic acid (HEPES, pH 7.4) containing $0.1 \%$ bovine serum albumine,
$0.2 \%$ D-glucose and $40 \mu \mathrm{M}$ essential amino acids minus methionine. After incubation, LH subunits were immunoextracted using antisera against denatured subunits. The precipitated material was purified and characterized by sodium dodecyl sulphate-polyacrylamide gel electrophoresis, and the corresponding radioactive bands were excised from the gels, solubilized with $\mathrm{H}_{2} \mathrm{O}_{2}$ and counted.

\section{$R N A$ preparation and hybridization}

RNA was extracted by lysis of incubated pituitary cells $\left(3 \times 10^{6} \mathrm{cells} / \mathrm{dish}\right)$ in guanidine- $\mathrm{HCl}$ and centrifugation through $\mathrm{CsCl}$ according to microscale method previously described (Counis et al., 1981). Total RNA was glyoxal denatured (McMasters and Carmichael, 1977), electrophoresed in $1.7 \%$ agarose and transferred onto nylon filters. Hybridizations were performed according to conventional procedures in $50 \%$ formamide, $5 \times \mathrm{SSC}$ $(1 \times \mathrm{SSC}=150 \mathrm{mM} \mathrm{NaCl}, 15 \mathrm{mM}$ trisodium citrate), $5 \times$ Denhardt's solution, $0.1 \%$ sodium sarcosinate, $50 \mathrm{mM}$ phosphate buffer, $\mathrm{pH} 6.5$ and $125 \mu \mathrm{g} / \mathrm{ml}$ denatured salmon sperm DNA, containing either of ${ }^{32}$ P-labelled $\alpha, \operatorname{LH} \beta$ or $\beta$-actin cDNA probes. After overnight hybridization at $42^{\circ} \mathrm{C}$, filters were washed twice at room temperature in the presence of $1 \times \mathrm{SSC}, 0.1 \%$ sarcosinate and twice in $0.1 \times \mathrm{SSC}, 0.1 \%$ sarcosinate, including one at $50 \mathrm{C}$. After autoradiography, semi-quantitative evaluation of mRNA levels was performed by densitometry.

\section{$c D N A$ probes and labelling}

The $\alpha$ and $\mathrm{LH} \beta$ rat cDNA probes are M13 recombinant subclones containing message-sense inserts which have been used as templates for cDNA synthesis with the Klenow fragment of $E$. coli DNA polymerase I and the M13 universal sequencing primer. After annealing of $2.5 \mathrm{ng}$ primer to $1 \mu \mathrm{g}$ recombinant M13 DNA for $30 \mathrm{~min}$ at $65^{\circ} \mathrm{C}$, the probe synthesis was achieved in $10 \mu \mathrm{l}$ of $30 \mathrm{mM}$ Tris-acetate buffer, $\mathrm{pH} 8$ containing $60 \mathrm{mM}$ potassium acetate, $9.5 \mathrm{mM}$ magnesium acetate, $0.5 \mathrm{mM}$ dithiothreitol, $100 \mu \mathrm{g} / \mathrm{ml}$ bovine serum albumin, $2.5 \mathrm{mM}$ each of dATP, dTTP, dGTP, $10 \mu \mathrm{Ci}\left[\alpha-{ }^{32} \mathrm{P}\right] \mathrm{dCTP}$ and $0.5 \mathrm{U}$ Klenow enzyme. After overnight incubation at room temperature, the radioactive cDNA probe (specific radioactivity $10^{9} \mathrm{cpm} / \mu \mathrm{g}$ ) was separated from cold M13 matrix by alkaline gel electrophoresis and recovered from the gel by heat melting in the hybridization buffer.

The $\beta$-actin probe, used as internal standard to control $\alpha$ and LH $\beta$ mRNA subunit measurements, was prepared by random priming of a $1150 \mathrm{bp}$ mouse cDNA insert contained in a pAL41 recombinant plasmid (Alonso et al., 1986). The labelling of the insert was performed according to the manufacturer's instructions (specific radioactivity $\left.2 \times 10^{9} \mathrm{cpm} / \mu \mathrm{g}\right)$.

\section{$L H$ radioimmunoassay}

LH in culture media was determined using a rat RIA kit (rat LHRP-2, NIADDK). All samples were assayed in duplicate.

\section{Statistical analysis}

Data are presented as means \pm SE of 2-3 independent experiments performed with duplicate or triplicate cultures. Differences between control and treated groups were assessed using Student's $t$-test, $P \leqslant 0.05$ being considered significant. 
(A)

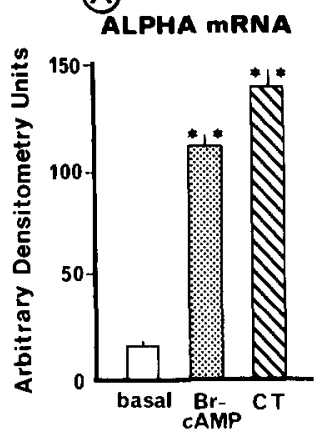

(C)

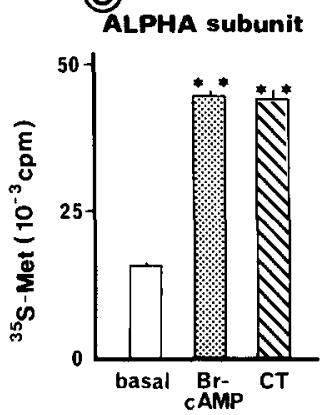

(B) LH BETA mRNA

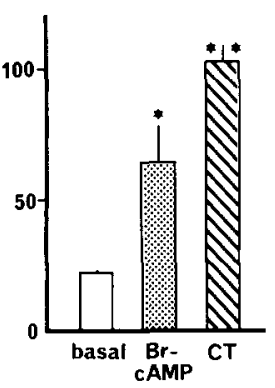

(D) LH BETA subunit

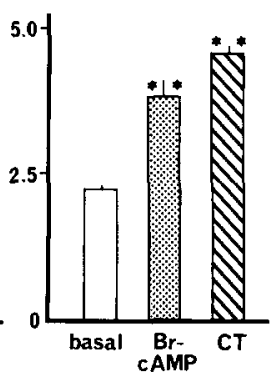

Fig. 1. Comparative effects of 8-Br-cAMP and cholera toxin on $\alpha$ and $\mathrm{LH} \beta$ mRNA levels and $\left[{ }^{35} \mathrm{~S}\right] \mathrm{Met}$ incorporation into polypeptide chains of $\alpha$ and LH $\beta$ subunits. Cultured pituitary cells $\left(3 \times 10^{6}\right.$ per dish) were incubated for $5 \mathrm{~h}$ in the presence of $1.5 \mathrm{mM} 8$-Br-cAMP (Br-cAMP) or $6 \mathrm{nM}$ cholera toxin (CT). The $\alpha(\mathrm{A})$ and $\mathrm{LH} \beta$ (B) mRNA were quantified in total RNA extracts by densitometry analysis of Northern blot hybridization (exposure time was 6-fold longer for $\mathrm{LH} \beta$ than for $\alpha \mathrm{mRNA})$. $\left[{ }^{35} \mathrm{~S}\right] \mathrm{Methionine}$ incorporation (cells + medium) into $\alpha(\mathrm{C})$ and $\mathrm{LH} \beta$ (D) subunits immunoextracted from total proteins and purified by gel electrophoresis, was determined by scintillation counting of the radioactivity. In each case, values are means \pm SE of 3 independent experiments performed in duplicate; ${ }^{*} P \leqslant 0.05$; ${ }^{* *} P \leqslant 0.01$ as compared to basal values.

\section{RESULTS}

Figure 1 shows the cell content of $\alpha$ and $\operatorname{LH} \beta$ mRNA and the ${ }^{35} \mathrm{~S}$-labelled neosynthesized subunits after a $5 \mathrm{~h}$-incubation in the presence or absence of $1.5 \mathrm{mM}$ Br-cAMP or $6 \mathrm{nM}$ cholera toxin. Both substances induced significant increase in $\alpha$ [Fig. 1(A)] and $\mathrm{LH} \beta$ [Fig. 1(B)] mRNA. Compared to basal levels, $\alpha$ mRNA increased 7.1-fold in the presence of $\mathrm{Br}$-cAMP and 8.9-fold in the presence of cholera toxin, this was a larger increase than that seen for LH $\beta$ mRNA, which increased 2.9- and 4.7-fold with $\mathrm{Br}$-cAMP and cholera toxin, respectively. The differences observed in the stimulatory effect of Br-cAMP as compared to cholera toxin although visible in

Fig. 1 for $\alpha$ and LH $\beta$ mRNA, were only significant in the case of the LH $\beta$ mRNA $(P \leqslant 0.05)$. During the same time period, $\left[{ }^{35} \mathrm{~S}\right] \mathrm{Met}$ incorporation into newly synthesized $\alpha$ [Fig. 1(C)] and LH $\beta$ [Fig. 1(D)] was significantly enhanced 2.8 -fold and 1.7 to 2.2 -fold, respectively, over basal synthesis, no significant difference was observed in the respective potency of $\mathrm{Br}$-cAMP or cholera toxin.

Table 1 shows a comparative study of the effects of Br-cAMP and GnRH on the synthesis of LH subunits, performed by immunoextracting ${ }^{35}$ S-labelled $\alpha$ and $\mathrm{LH} \beta$ polypeptides separately from cells and media after a 5 h-incubation. As previously reported (Starzec et al., 1988b), large amounts of the neosynthesized $\alpha$ subunit was spontaneously exported into the medium in basal conditions, while the $\operatorname{LH} \beta$ was exported only in traces. Table 1 shows that presence of $1.5 \mathrm{mM}$ Br-cAMP as well as $10 \mathrm{nM} \mathrm{GnRH}$ in the cell culture stimulated the release of newly synthesized $\alpha$ and $\mathbf{L H} \beta$ subunits in addition to $\left[{ }^{35} \mathrm{~S}\right] \mathrm{Met}$ incorporation. Thus, in the conditions used, $\left[{ }^{35} \mathrm{~S}\right]$ Met incorporation into total (cells + medium) $\alpha$ subunit increased 2.7-fold in the presence of GnRH and 2.8-fold in the presence of Br-cAMP (no significant difference). The radioactive $\alpha$ released into the medium from non stimulated cells (basal) represented $65 \%$ of the total neosynthesized subunit. In the presence of GnRH, 78\% of the $\left[{ }^{35} \mathrm{~S}\right] \alpha$ was released and in the presence of Br-cAMP, 94\%. In parallel, GnRH like Br-cAMP increased the amount of $\left[{ }^{35} \mathrm{~S}\right] \mathrm{Met}$ incorporated into total $\mathrm{LH} \beta$, by 2.1 - and 2.7-fold, respectively (no significant difference). The percentage of total neosynthesized $\mathrm{LH} \beta$ that was released in the medium was $5 \%$ in basal conditions and in response to GnRH or Br-cAMP, 14.4 and $40.4 \%$, respectively. During the same time period, $10 \mathrm{nM}$ GnRH induced a 5 -fold increase in the release of radioimmunoassayable $\mathrm{LH}$ and $1.5 \mathrm{mM} \mathrm{Br}$-cAMP only produced a 1.4 -fold (non significant) increase.

\section{DISCUSSION}

Since GnRH has been shown to be capable of inducing an increase in cAMP production, the role of the cyclic nucleotide within the gonadotropic cell has generated controversy especially regarding its possible involvement in the release of gonadotropins (Borgeat et al., 1972; Kaneko et al., 1973; Makino, 1973; Conn et al., 1979; Sen and Menon, 1979; Bérault et al., 1980). In the present study, we provide the first evidence that cAMP stimulates accumulation of $\alpha$ and LH $\beta$ mRNAs in anterior pituitary cells. Indeed it is evident that the increased synthesis of $\alpha$ 
Table 1. Effects of 8-Br-cAMP and GnRH on synthesis and release of neosynthesized $\alpha$ and LH $\beta$ subunits and on release of stored $\mathrm{LH}$

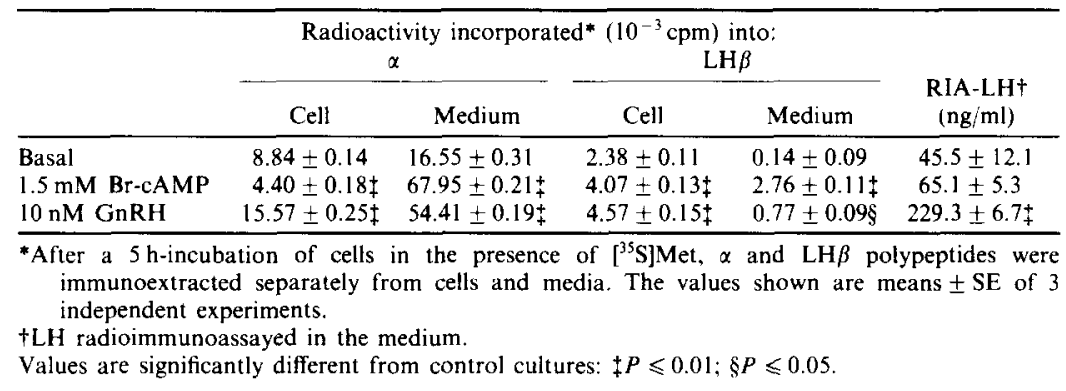

and $\operatorname{LH} \beta$ subunits is mediated by increased levels of the corresponding mRNA. In the same experimental conditions, Br-cAMP or cholera toxin had no effect on the level of $\beta$-actin mRNA used as reference (not shown). However, quantitative evaluation of specific mRNA levels in parallel to neosynthesized LH subunits showed that after a $5 \mathrm{~h}$-incubation, the mRNA and protein levels were not increased in the same proportion. In particular, a large increase (approx. 7 to 9 -fold) in $\alpha$ mRNA was associated with a 2.8 -fold increase in $\alpha$ subunit. On the other hand, $\mathrm{LH} \beta$ mRNA increased by approx. 3 to 5-fold, while $\mathrm{LH} \beta$ subunit increased by 1.7 to 2.2 -fold. As the concentrations of Br-cAMP and cholera toxin employed in this study caused optimal increase in LH subunit synthesis (Starzec et al., 1989), it is interesting to note that there is no direct correlation between the changes in mRNA and protein subunit levels. Among several possibilities, one may suggest that only one part of the specific mRNA that accumulates is fully translatable, or that rapid and large rise in mRNA may saturate the translation machinery as observed in vitro (Counis et al., 1982). Further investigation is necessary to clarify this point.

It is now well established that cAMP can affect the synthesis of a number of specific proteins. In the pituitary gland, prolactin (Waterman et al., 1985), growth hormone (Waterman et al., 1985; Barinaga et al., 1985), proopiomelanocortin (Lundblad and Roberts, 1988) are regulated by cAMP as well as the $\alpha$ and $\beta$ subunits of the LH-related human chorionic gonadotropin (hCG) in the placenta. Using chimeric gene constructions, cAMP regulatory elements have been identified along the $5^{\prime}$ flanking regions of the $\alpha$ gene (Darnell and Boime, 1985) sharing with others a consensus nucleotide sequence, which can account for transcriptional control of its activity (Burnside $e t$ al., 1985; Jameson et al., 1986, 1988; Milsted et al., 1987). The same methodology recently showed cAMP responsive regulatory domain in a $2 \mathrm{~kb} 5^{\prime}$ flanking region of the LH $\beta$ gene (Lalloz et al., 1988b). Therefore, the increased $\alpha$ and LH $\beta$ mRNAs in cultured pituitary cells in response to Br-cAMP or cholera toxin reported in this work most likely result from increased transcription of the genes.

Although the $\alpha$ gene is expressed in both thyrotrophs and gonadotrophs, it is clear that cAMP operates in gonadotrophs since LH $\beta$ mRNA increased. Thus, cAMP, the diacylglycerol analogue TPA and GnRH can all stimulate $\alpha$ and LH $\beta$ mRNA accumulation, as well as polypeptide subunit synthesis. Therefore, both cAMP and diacylglycerol are good candidates as mediators of the GnRH effect on LH synthesis. Further, as they act in a non additive manner (Starzec et al., 1989), the question arises of their respective roles in the control of $\mathbf{L H}$ gene expression.

Another point of interest to the discussion is the relationship between the regulation of synthesis and release of gonadotropins. With regard to this, diacylglycerols and protein kinase $\mathrm{C}$ activation may play a pivotal role in the GnRH control since they participate, in synergy with $\mathrm{Ca}^{2+}$ and inositol triphosphate, in the LH release (Harris et al., 1985; Naor and Eli, 1985; Chang et al., 1988), subunit synthesis (Starzec et al., 1989) and mRNA accumulation (Andrews et al., 1988; Starzec et al., al preparation). A role of cAMP in the rapid release of gonadotropin has been ruled out (Bérault et al., 1980); our data showing only a weak effect of Br-cAMP compared to that of $\mathrm{GnRH}$ on LH release after $5 \mathrm{~h}$-incubation are consistent with previous data from this laboratory and others (Naor et al., 1978; Conn et al., 1979; Sen and Menon, 1979). Contrasting with its low efficiency in inducing release of stored $\mathrm{LH}$, cAMP readily stimulates, in addition to subunit production and like GnRH, release of newly synthesized $\alpha$ and $\operatorname{LH} \beta$ polypeptides. The method of electrophoresis employed in the study for the isolation and identification of the newly synthesized subunits did not allow us to 
discriminate associated and non associated forms of LH. However, regarding the large excess of the radioactive $\alpha$ over $\mathrm{LH} \beta$ found in the medium whatever the experimental conditions, it appeared evident that the neosynthesized $\alpha$ subunit is predominantly released in a free state. Moreover, the $\alpha$ subunit isolated in the medium comprised a large proportion (approx. 50\%, not shown) of a presumably $O$-glycosylated form which is unable to combine with $\mathrm{LH} \beta$ (Parsons and Pierce, 1984; Starzec et al., 1986, 1988b and unpublished data). How newly synthesized LH material is preferentially released from gonadotropic cells is to-date difficult to interpret, especially in terms of passive or active process (Kelly, 1985). In cell lines derived from placental tissue, where very little hCG exists as stored hormone, cAMP stimulation of hCG release results mostly from increased biosynthesis (Hussa, 1980; Jameson et al., 1986). In the pituitary, $\mathrm{LH}$ released in response to $\mathrm{GnRH}$ has been reported to consist of two pools of the hormone: one is protein synthesis-independent and its release is rapid, the other is protein synthesis-dependent and its release is delayed, as is the accumulation of cAMP in response to GnRH stimulation (Naor et al., 1978). Since cAMP has no effect on acute release of (stored) LH, we postulate according to Tang et al. (1984), Bourne and Baldwin (1987) and Starzec et al. (1988a) that the cAMP generated in gonadotrophs in response to $\mathrm{GnRH}$ is responsible for the sustained release of $\mathbf{L H}$ in terms of increased synthesis and release of the neosynthesized hormone. Thus regarding the release of stored LH and neosynthesized LH, GnRH has dual effects, while cAMP shows discrimination. Therefore these data are consistent with our hypothesis previously proposed (Starzec et al., 1989), of a cascade reaction induced by GnRH stimulation of gonadotrophs, consisting of sequential activation of protein kinase $\mathrm{C}$ and then protein kinase $\mathrm{A}$, the former being involved in acute release of $\mathrm{LH}$, the latter in the synthesis of $\mathrm{LH}$ subunits leading to sustained release and restoration of $\mathrm{LH}$ stocks.

Acknowledgements - We are grateful to Dr J. G. Pierce for his generous gifts of antisera to denatured bovine $\mathrm{LH}$ subunits, and Drs M. Buckingham and S. Alonso for providing us with a mouse $\beta$-actin cDNA clone. We are indebted to Dr A. Bérault and A. Ricourt for performing RIA, and Dr C. Herbert for correction of the English text and for editorial help. We also wish to thank NIADDK, the National Hormone and Pituitary Program, University of Maryland, School of Medicine, Baltimore, Md, U.S.A. for rat LH RIA kit. This study was supported by a grant from the Institut National de la Santé et de la Recherche Médicale (CRE No. 864 005) and from the Fondation de Recherche en Hormonologie (Contract No. 9188007). A. S. was the recipient of a Fellowship from La Société de Secours des Amis des Sciences, M. M. from the Association pour la Recherche sur le Cancer and Y. L. from the Ligue Nationale Française Contre le Cancer.

\section{REFERENCES}

Alonso S., Minty A., Bourlet Y. and Buckingham M. (1986) Comparison of three actin-coding sequences in the mouse: evolutionary relationships between the actin genes of warm-blooded vertebrates. J. molec. Evol. 23, 11-12.

Andrews W. V., Maurer R. A. and Conn P. M. (1988) Stimulation of rat luteinizing hormone- $\beta$ messenger RNA levels by gonadotropin releasing hormone. Apparent role for protein kinase C. J. biol. Chem. 263, 13755-13761.

Baringa M., Bilezikjian L. M., Vale W. V., Rosenfeld M. G. and Evans R. M. (1985) Independent effects of growth hormone releasing factor on growth hormone release and gene transcription. Nature 314, 279-281.

Bérault A., Théoleyre M., Colléaux Y. and Jutisz M. (1980) Further evidence that cyclic AMP is not the mediator of the releasing action of GnRH. Neuroendocr. Lett. 2, 31-37.

Borgeat P., Chavancy G., Dupont A., Labrie F., Arimura A. and Schally A. V. (1972) Stimulation of adenosine $3^{\prime}, 5^{\prime}$-cyclic monophosphate accumulation in anterior pituitary gland in vitro by synthetic luteinizing hormonereleasing hormone. Proc. natn. Acad. Sci. U.S.A. 69, 2677-2681.

Bourne G. A. and Baldwin D. M. (1987) Evidence for cAMP as a mediator of gonadotropin secretion from female pituitaries. Am. J. Physiol. 253, E290-E295.

Burnside J., Nagelberg S. B., Lippman S. S. and Weintraub B. D. (1985) Differential regulation of hCG $\alpha$ and $\beta$ subunit mRNAs in JEG-3 choriocarcinoma cells by 8-bromo-cAMP. J. biol. Chem. 260, 12705-12709.

Chang J. P., Stojilkovic S. S., Graeter J. S. and Catt K. J. (1988) Gonadotropin-releasing hormone stimulates luteinizing hormone secretion by extracellular calciumdependent and -independent mechanisms. Endocrinology 122, 87-97.

Conn P. M., Morrell D. V., Dufau M. L. and Catt K. J. (1979) Gonadotropin-releasing hormone action in cultured pituicytes: independence of luteinizing hormone release and adenosine $3^{\prime}, 5^{\prime}$-monophosphate production. Endocrinology 104, 404-453.

Counis R., Corbani M. and Jutisz M. (1982) Studies on cell-free biosynthesis of lutropin (LH) and characterization of its subunit precursors. In: Pituitary Hormones and Related Peptides (Motta M., Zanisi M. and Piva F., eds), pp. 49-61. Academic Press, London.

Counis R., Corbani M., Bérault A., Théoleyre M., Jansem M. T. and Jutisz M. (1981) Une microméthode permettant de préparer et de traduire l'acide ribonucléique messager à partir de cellules adénohypophysaires en culture. C.r. Acad. Sci. Paris, Sér. III 293, 115-118.

Darnell R. B. and Boime I. (1985) Differential expression of the human gonadotropin $\alpha$ gene in ectopic and eutopic cells. Molec. cell. Biol. 5, 3157-3163.

Hamernik D. L. and Nett T. M. (1988) Gonadotropinreleasing hormone increases the amount of messenger ribonucleic acid for gonadotropins in ovariectomized ewes after hypothalamic-pituitary disconnection. Endocrinology 122, 959-966. 
Harris C. E., Staley D. and Conn P. M. (1985) Diacylglycerols and protein kinase $C$. Potential amplifying mechanism for $\mathrm{Ca}^{2+}$-mediated gonadotropin-releasing hormonestimulated luteinizing hormone release. Molec. Pharmac. 27, 532-541.

Hubert J. F., Simard J., Gagné B., Barden N. and Labrie F. (1988) Effect of luteinizing hormone-releasing hormone (LHRH) and [D-Trp ${ }^{6}$, Des-Gly-NH $\left.{ }_{2}^{10}\right] \mathrm{LHRH}$ ethylamide on $\alpha$-subunit and $\mathrm{LH} \beta$ messenger ribonucleic acid levels in rat anterior pituitary cells in culture. $\mathrm{Molec}$. Endocr. 2, 521-527.

Hussa R. O. (1980) Biosynthesis of human chorionic gonadotropin. Endocr. Rev. 1, 268-294.

Jameson J. L., Jaffe R. C., Gleason S. L. and Habener J. F. (1986) Transcriptional regulation of chorionic gonadotropin $\alpha$ - and $\beta$-subunit gene expression by 8 bromo-adenosine $3^{\prime}-5^{\prime}$-monophosphate. Endocrinology 119, $2560-2567$.

Jameson J. L., Jaffe R. C., Deutsch P. J., Albanese C. and Habener J. F. (1988) The gonadotropin $\alpha$-gene contains multiple protein binding domains that interact to modulate basal and cAMP-responsive transcription. $J$. biol. Chem. 263, 9879-9886.

Kalra S. P. and Kalra P. S. (1983) Neural regulation of luteinizing hormone secretion in the rat. Endocr. Rev. 4, 311-351.

Kaneko T., Saito S., Oka H., Oda T. and Yanaihara N. (1973) Effect of synthetic LH-RH and its analogs on rat anterior pituitary cyclic AMP and LH and FSH release. Metabolism 22, 77-85.

Kelly R. B. (1985) Pathways of protein secretion in eukaryotes. Science 230, 25-32.

Lalloz M. R. A., Detta A. and Clayton R. N. (1988a) Gonadotropin-releasing hormone is required for enhanced luteinizing hormone subunit gene expression in vivo. Endocrinology 122, 1681-1688.

Lalloz M. R. A., Smith S. R., Detta A., Powell J. and Clayton R. N. (1988b) Regulated expression of the LH $\beta$ CAT fusion gene in HPT-2 cells. J. Endocr. 119, Suppl., Abstract 55

Leung K., Kaynard A. H., Negrini B. P., Kim K. E., Maurer R. A. and Landefeld T. D. (1987) Differential regulation of gonadotropin subunit messenger ribonucleic acids by gonadotropin-releasing hormone pulse frequency in ewes. Molec. Endocr. 1, 724-728.

Lundblad J. R. and Roberts J. L. (1988) Regulation of proopiomelanocortin gene expression in pituitary. Endocr. Rev. 9, 135-158.

Makino T. (1973) Study on the intracellular mechanism of LH release in the anterior pituitary. Am. J. Obstet. Gynecol. 115, 606-613.

McMasters G. K. and Carmichael G. G. (1977) Analysis of single- and double-stranded nucleic acids on polyacrylamide and agarose gels by using glyoxal and acridine orange. Proc. natn. Acad. Sci. U.S.A. 74, 4835-4838.

Milsted A., Cox R. P. and Nilson J. H. (1987) Cyclic AMP regulates transcription of the genes encoding human chorionic gonadotropin with different kinetics. DNA 6, 213-219.

Naor Z. and Eli Y. (1985) Synergistic stimulation of luteinizing hormone $(\mathrm{LH})$ release by protein kinase $\mathrm{C}$ activators and $\mathrm{Ca}^{2+}$-ionophore. Biochem. biophys. Res. Commun. 130, 848-853.

Naor Z., Fawcett C. P. and McCann S. M. (1978) Involvement of cGMP in LHRH-stimulated gonadotropin release. Am. J. Physiol. 235 (Endocr. Metab. Gastrointest. Physiol. 4), E586-E590.

Papavasiliou S. S., Zmeili S., Khoury S., Landefeld T. D., Chin W. W. and Marshall J. C. (1986) Gonadotropinreleasing hormone differentially regulates expression of the genes for luteinizing hormone $\alpha$ and $\beta$ subunits in male rats. Proc. natn. Acad. Sci. U.S.A. 83, 4026-4029.

Parsons T. F. and Pierce J. G. (1984) Free $\alpha$-like material from bovine pituitaries. Removal of its $\mathrm{O}$-linked oligosaccharide permits combination with lutropin- $\beta$. J. biol. Chem. 259, 2662-2666.

Ramey J. W., Highsmith R. F., Wilfinger W. W. and Baldwin D. M. (1987) The effects of gonadotropinreleasing hormone and estradiol on luteinizing hormone biosynthesis in cultured rat anterior pituitary cells. Endocrinology 120, 1503-1513.

Sen K. K. and Menon K. M. J. (1979) Dissociation of cyclic AMP accumulation from that of luteinizing hormone (LH) release in response to gonadotropin releasing hormone (GnRH) and cholera enterotoxin. Biochem. biophys. Res. Commun. 87, 221-228.

Starzec A., Counis R. and Jutisz M. (1986) Gonadotropinreleasing hormone stimulates the synthesis of the polypeptide chains of luteinizing hormone. Endocrinology 119, $561-565$.

Starzec A., Jutisz M. and Counis R. (1988a) Detection of a lag phase in gonadotropin-releasing hormone stimulated synthesis of lutropin peptide chains in cultured rat anterior pituitary cells. Biochem. biophys. Res. Commun. 153, 664670 .

Starzec A., Counis R. and Jutisz M. (1988b) Several intermediate forms in the processing of rat lutropin subunits as shown by sodium dodecyl sulphate polyacrylamide gel electrophoresis. J. Chromat. 440, 353-360.

Starzec A., Jutisz M. and Counis R. (1989) Cyclic AMP and phorbol ester, like gonadotropin-releasing hormone, stimulate the biosynthesis of luteinizing hormone polypeptide chains in a non additive manner. Molec. Endocr. 3, 618-624.

Tang L. K., Martellock A. C. and Tang F. Y. (1984) Effect of testosterone on gonadotropin response to DBcAMP, cAMP binding, and cAMP production in pituitary cultures. Am. J. Physiol. 247 (Endocr. Metab. 10), E312-E317.

Waterman M., Murdoch G. H., Evans R. M. and Rosenfeld M. G. (1985) Cyclic AMP regulation of eukaryotic gene transcription by two discrete molecular mechanisms. Science 229, 267-269. 